\title{
HeLa ve Beas-2B Hücre Hatlarına Karşı Benzimidazolyum Tuzlarının İn Vitro Sitotoksik Aktivite Çalışmaları
}

\author{
In Vitro Cytotoxic Activity Studies of Benzimidazolium Salts against HeLa and Beas-2B Cell \\ Lines
}

\section{Senem AKKOÇ*}

Eczacılık Fakültesi, Temel Eczacllık Bilimleri Bölümü, Süleyman Demirel Üniversitesi, Isparta

• Geliş tarihi / Received: 31.08 .2019 •Düzeltilerek geliş tarihi / Received in revised form: 02.03.2020 • Kabul tarihi / Accepted: 07.03.2020

\begin{abstract}
Öz
1H-benzo[d]imidazol çekirdeği içeren altı farklı heterosiklik bileşik (S1-S6) iki basamakta hazırlandı ve yapıları farklı spektroskopik yöntemler kullanılarak karakterize edildi. Sentezlenen heterosiklik bileşikler insan serviks adenokarsinom (HeLa) ve insan sağlıklı akciğer (Beas-2B) hücre hatlarına karşı test edildi. Pozitif kontrol ilaç olarak cisplatin aynı şartlar altında serviks hücre hattına karşı denendi. Bileşik S4'ün HeLa hücre hattına karşı yüksek sitotoksik aktivite gösterdiği (IC50: $3.72 \pm 0.14 \mu \mathrm{M}$ ) bulundu. Çalışmanın son basamağında, ilaç adayları ile etkileştirilen hücrelerin renkli görüntüleri konfokal mikroskobu kullanılarak alındı.
\end{abstract}

Anahtar kelimeler: Benzimidazol, Heterosiklik Bileşik, Konfokal, Sitotoksik Aktivite.

\begin{abstract}
Six different heterocyclic compounds containing 1H-benzo[d]imidazole nuclei (S1-S6) were prepared in two steps and their structures were characterized using different spectroscopic methods. The synthesized heterocyclic compounds were tested against human cervix adenocarcinoma (HeLa) and human healthy lung (Beas-2B) cell lines. Cisplatin as a positive control drug was tested against the cervix cell line under the same conditions. Compound S4 was found to exhibit high cytotoxic activity against HeLa cell line (IC50: $3.72 \pm 0.14 \mu \mathrm{M}$ ). In the last step of the study, color images of the cells interacted with the drug candidates were taken using confocal microscope.
\end{abstract}

Keywords: Benzimidazole, Heterocyclic Compound, Confocal, Cytotoxic Activity.

* Senem AKKOÇ; senemakkoc@sdu.edu.tr, senemakkoc44@gmail.com, Tel: +90 246211 03 38, orcid.org/0000-0002-1260-9425 


\section{Giriş}

İnsanların yaşam kalitesini etkileyen ve ölümlerin başta gelen nedenleri arasında yer alan kanser, her yıl dünyada milyonlarca insanın hayatını kaybetmesine neden olmaktadır. Dünya Sağlık Örgütü'nün araştırmasına göre, dünyada her beş erkekten biri ve her altı kadından biri kansere yakalanmakta ve sekiz erkekten biri ve on bir kadından biri de kanser nedeni ile yaşamını yitirmektedir (World Health Organization, 2018).

Günümüzde organik bileşikler ve doğal ürünleri içeren birçok kemoterapi ilacı bulunmaktadır. Kemoterapi tedavisinde özellikle cisplatin (Rosenberg vd., 1969), karboplatin (Busschots vd., 2015), oksaliplatin (To vd., 2016) ve satraplatin (Wheate vd., 2010) gibi farklı platin bazlı ilaçlar kullanılmaktadır. Yumurtalık, testis, gögüs kanseri ve melanoma gibi tümörlerin farklı tiplerinin tedavileri metal bazlı antikanser ajanlar arasında önemli bir yere sahip olan bu platinyum temelli aktif ilaçlar kullanılarak yapılmaktadır. Öte yandan, platin içeren bu ilaçların sadece belli tümörlerin tedavisinde kullanılabilmeleri ve miyelosupresyon (kemik iliği aktivitesinde azalma), ototoksisite (işitme kaybı), nörotoksisite (sinir sistemi hasarı) ve nefrotoksisite (böbrek fonksiyonlarının azalması ve hasar) gibi birçok yan etkisinin olmasi (Yang vd., 2019) ve kemoterapötik kanser ajanlarına karşı ilaç direncinin artarak büyümesi ciddi bir tıbbi problem yaratmaktadır. $\mathrm{Bu}$ nedenle, kanser tedavisi için yeni, etkin ve güvenli kemoterapötik ilaç adaylarının geliştirilmesine büyük bir ihtiyaç vardır.

Benzimidazol halkası, farklı terapötik alanlarda kullanılan birçok önemli ilacın (antihistaminikler, antihelminikler, proton pompa inhibitörleri ve anjiyotensin reseptör antagonisti) elde edildiği bir tür ayrıcalıklı iskelet yapısına sahiptir (Bansal ve Silakari, 2012). Benzimidazol temelli heterosiklik bileşiklerin antibakteriyal (Gök vd., 2013; Gök vd., 2015), antiviral (Tonelli vd., 2014; Cheng vd., 2005), antiparazit (Rojas-Aguirre vd., 2012; Farahat vd., 2018), antikanser (Aslan vd., 2020; Akkoç, 2019a; Akkoç, 2019b; Akkoç vd., 2019; Akkoç vd., 2017; Akkoç vd., 2016), antienflamatuar (Sharma vd., 2017), antioksidan (Abdelgawad vd., 2019), antiglikasyon (Taha vd., 2018), antidiyabetik (Shingalapur vd., 2010) ve glukozidaz inhibitörleri (Özil vd., 2018) gibi farklı biyolojik aktivite özelliklerinden dolayı kimyada oldukça önemli bir yeri vardır. Benzimidazol çekirdeği üzerindeki çeşitli sübstitüentler ile bu geniş biyolojik aktivite yelpazesi sağlanabilmektedir.
Ticari olarak satılan ve benzimidazol çekirdeği içeren çok sayıda ilaç örneği vardır. Örneğin; Bendamustin, kronik lenfositik lösemi, multipl miyelom ve Hodgkin olmayan lenfoma tedavisinde kullanılan bir kemoterapi ilacıdır. Karbendazim, yaygın olarak kullanılan, geniş spektrumlu bir benzimidazol fungisit ve bir benomil metabolitidir. Fenbendazole, gastrointestinal parazitlere karşı kullanılan antelmintik bir ilaçtır. Kandesartan, yüksek tansiyon ve konjestif kalp yetmezliği tedavisinde kullanılan bir anjiyotensin reseptör blokeridir. Telmisartan, hipertansiyon, kalp yetmezliği ve diyabetik böbrek hastalığını tedavi etmek için kullanılan bir ilaçtır. Maribavir, hematopoetik kök hücre / kemik iliği nakil hastalarında insan sitomegalo virüs hastalığının önlenmesi ve tedavisi için kullanılan bir antiviral ilaçtır.

Benzimidazol türevlerinin bu kadar geniş biyolojik aktivite özelliklerinden dolayı bu çalışmada, ilk olarak benzimidazolden yola çıkarak farklı N-alkilbenzimidazol türevleri sentezlendi. İkinci basamakta, sentezlenen $\mathrm{N}$ alkilbenzimidazol türevleri ile farklı aril halojenürler etkileştirilerek benzimidazolyum tuzları hazırlandı ve yapıları spektroskopik yöntemler ile aydınlatıldı. Son olarak, bu bileşiklerin normal ve kanserli hücre hatlarındaki sitotoksik aktiviteleri test edilerek birbiri ile karşılaştırıldı. İlaç adayları ile muamele edilen hücrelerin renkli görüntüleri konfokal mikroskobu ile alınarak hücrelerin canlılık oranları tespit edildi.

\section{Gereç ve Yöntem}

\subsection{Kullanılan Reaktif ve Çözgenler}

Gerekli reaktiflerin bazıları yapılan çalışmada sentezlenirken bazıları da ticari olarak satın alındı. 3-Metilbenzil bromür, 4-metilbenzil bromür, 2(bromometil) benzonitril, 4-vinilbenzil klorür, 9(klorometil)antrasen, N-(4-bromobütil)fitalimit, $\mathrm{N}$-(2-kloroetil)piperidin hidroklorür, $N, N$ dimetilformamit (DMF), potasyum hidroksit $(\mathrm{KOH})$, etil alkol ve dietil eter gibi reaktif ve çözgenler analitik saflıkta olup Merck (Darmstadt, Almanya), Sigma-Aldrich (Interlab A.S., ABD), Alfa-Aesar (Massachusetts, ABD) veya Scharlau (Barselona, İspanya) firmalarından satın alındı.

Serviks kanser hücre hattı (HeLa) ile insan sağlıklı akciğer hücre hattı (Beas-2B) ATCC'den satın alındı. DMEM, FBS, glutamax, PBS ve trypsin-EDTA Gibco firmasından satın alındı. Cis-diaminplatinyum (II) diklorür ve 3-(4,5dimetiltiyazol-2-il)-2,5-difenil tetrazolyum 
bromür (MTT) Sigma-Aldrich firmasından tedarik edildi. Hoechst 33258, pentahidrat (bis-benzimid) ve propidyum iyodür (PI) boyalar1 ThermoFisher Scientific firmasından satın alındı. Doku kültürü flaskları ve 96 kuyucuklu plakalar Jet Biofil firmasından satın alındi.

\subsection{Benzimidazolyum Tuzlarının Sentezi}

S1-S3, S5, S6 bileşikleri (Akkoç vd., 2019) ile S4 (Akkoç, 2019a) bileşiği literatüre göre hazırlandı. Benzimidazol (1 mmol) ve potasyum hidroksit (1 mmol) etil alkol (40 mL) içerisinde çözüldü. Tepkime karışımı bir saat oda sıcaklığında karıştırıldıktan sonra reaksiyon ortamına aril/alkil halojenür $(1 \mathrm{mmol})$ yavaş yavaş ilave edildi ve 6 saat refluks edildi. Daha sonra reaksiyon karışımı oda sicaklığına soğutularak oluşan potasyum klorür tuzu süzülerek ortamdan uzaklaştırıldı. Başlangıç maddesi kristallendirilerek saflaştırıldı. Elde edilen $\mathrm{N}$-aril/alkil benzimidazol (1 mmol) ile aril halojenür (1 mmol) DMF de çözüldü ve tepkimenin gerçekleşmesi için reaksiyon 24 saat $80{ }^{\circ} \mathrm{C}^{\prime}$ de karıştırılarak devam ettirildi. Tepkime tamamlandıktan sonra ortamdaki DMF vakum uygulanarak uzaklaştıııldı. Kristallendirilerek saflaştırılan bileşiklerin spektroskopik karakterizasyon sonuçları aşağıdaki gibidir.

\section{1-[4-(1,3-Dioksoizoindolin-2-il)butil]-3-(4-metilbenzil)benzimidazolyum bromür, S1}

Verim: \%33, e.n.: $263-266{ }^{\circ} \mathrm{C}$, renk: beyaz. IR: $1544.9,1737.7 \mathrm{~cm}^{-1} .{ }^{1} \mathrm{H}$ NMR $\left(400.13 \mathrm{MHz}, \mathrm{CDCl}_{3}\right), \delta$ : 1.88, 2.16-2.40, 2.89, 5.83, 6.01, 7.14-7.86, 11.56. ${ }^{13} \mathrm{C}$ NMR (100.13 MHz, $\left.\mathrm{CDCl}_{3}\right), \delta: 21.19,21.20,21.25$, $34.56,51.52,51.55,113.81,127.08,128.29,129.50,130.07,131.25,131.41,131.97,132.18,134.19,139.32$, $142.77,167.70$.

\section{1-(2-Siyanobenzil)-3-[4-(1,3-dioksoizoindolin-2-il)butil]benzimidazolyum bromür, S2}

Verim: \%58, e.n.: $186-189^{\circ} \mathrm{C}$, renk: beyaz. IR: $1562.9,1704.4,2943.9 \mathrm{~cm}^{-1} .{ }^{1} \mathrm{H} \mathrm{NMR}\left(400.13 \mathrm{MHz}, \mathrm{CDCl}_{3}\right)$, $\delta: 1.89,2.16,3.80,4.78,6.17,7.31-8.18,11.56 .{ }^{13} \mathrm{C} \mathrm{NMR}\left(100.13 \mathrm{MHz}, \mathrm{CDCl}_{3}\right), \delta: 25.57,26.63,36.62$, 47.22, 48.92, 112.03, 113.18, 113.59, 117.26, 123.36, 123.38, 127.27, 127.56, 127.72, 130.09, 131.04, $131.29,131.91,133.34,134.11,134.15,134.59,135.77,143.44,168.43$.

\section{1-[4-(1,3-Dioksoizoindolin-2-il)butil]-3-(4-vinilbenzil)benzimidazolyum bromür, S3}

Verim: \%60, e.n.: $110-112{ }^{\circ} \mathrm{C}$, renk: krem. IR: $1557.6,1699.3,2931.3,3069.8 \mathrm{~cm}^{-1}$. ${ }^{1} \mathrm{H}$ NMR $(400.13 \mathrm{MHz}$, $\left.\mathrm{CDCl}_{3}\right), \delta: 1.87,2.13,3.78,4.75,5.28,5.75,5.88,6.66,7.38-7.83,11.55 .{ }^{13} \mathrm{C} \mathrm{NMR}\left(100.13 \mathrm{MHz}, \mathrm{CDCl}_{3}\right)$, $\delta: 25.57,26.62,36.69,46.93,51.27,113.13,113.86,115.24,123.36,127.10,127.23,128.66,131.13,131.44$, $132.89,131.93,134.14,135.82,138.48,142.99,168.43$.

\section{1-(3-Metilbenzil)-3-(2-(piperidin-1-il)etil)benzimidazolyum klorür, S4}

Verim: \%85, e.n.: $154-155^{\circ} \mathrm{C}$, renk: kahve rengi. IR: $1558.4 \mathrm{~cm}^{-1} .{ }^{1} \mathrm{H} \mathrm{NMR}\left(400 \mathrm{MHz}, \mathrm{CDCl}_{3}\right), \delta: 1.17-1.67$, $2.34,2.67,3.48,4.91,5.78,7.15-7.96,11.40 .{ }^{13} \mathrm{C} \mathrm{NMR}\left(100 \mathrm{MHz}, \mathrm{CDCl}_{3}\right), \delta: 15.28,21.35,23.50,25.29$, $44.30,51.62,56.10,113.48,113.77,125.21,127.02,127.08,128.76,129.25,130.06,131.00,131.62,132.62$, 139.36, 143.97 .

\section{1-[4-(1,3-Dioksoizoindolin-2-il)butil]-3-(3-metilbenzil)benzimidazolyum bromür, S5}

Verim: \% 78, e.n.: $219-221^{\circ} \mathrm{C}$, renk: beyaz. IR: 1557.7, $1699.5,2955.1 \mathrm{~cm}^{-1} .{ }^{1} \mathrm{H}$ NMR $\left(400.13 \mathrm{MHz}, \mathrm{CDCl}_{3}\right)$, $\delta: 1.90,2.14,2.34,3.79,4.77,5.82,7.15-7.83,11.54 .{ }^{13} \mathrm{C} \mathrm{NMR}\left(100.13 \mathrm{MHz}, \mathrm{CDCl}_{3}\right), \delta: 21.36,25.59$, $26.65,36.69,46.95,51.60,113.12,113.85,123.36,125.35,127.22,128.93,129.26,130.10,131.22,131.46$, $131.91,132.41,134.13,139.39,143.01,168.43$.

\section{1-(Antrasen-10-ilmetil)-3-(2-siyanobenzil)benzimidazolyum klorïr, S6}

Verim: \%35, e.n.: $227-228^{\circ} \mathrm{C}$, renk: sar1. IR: $1553.9,2216.5,2940.2,3133.9 \mathrm{~cm}^{-1} .{ }^{1} \mathrm{H}$ NMR $(400.13 \mathrm{MHz}$, DMSO-d 6 , $298 \mathrm{~K}), \delta: 5.86,6.79,7.07-8.92,9.17 .{ }^{13} \mathrm{C}$ NMR (100.13 MHz, DMSO-d $\left.6,298 \mathrm{~K}\right), \delta: 48.67$, $56.47,110.67,114.17,115.06,117.17,122.19,123.94,126.13,127.49,127.81,127.97,128.33,129.62$, $129.90,131.01,131.50,131.61,131.89,132.32,134.07,134.25,137.97,142.93$.

\subsection{Senteżlenen Bileşiklerin İn Vitro Sitotoksik Aktivite Çalışmaları}

In vitro sitotoksik aktivite çalışmaları literatüre göre yapıldı (Akkoç, 2019a; Akkoç, 2019b;
Akkoç vd., 2019; Akkoç vd., 2017; Akkoç vd., 2016). İnsan serviks kanser hücre hatt1 (HeLa) ve insan normal (kanserli olmayan) akciğer hücre hatt1 (Beas-2B) \%10 FBS-\%90 DMEM ortamında kültür edildi. Hücreler, steril 96 kuyucuklu 
plakalara $1 \times 10^{3}$ hücre/kuyucuk yoğunluğunda ekildi. Plakalar $37^{\circ} \mathrm{C}$ ve $\% 5 \mathrm{CO}_{2}$ içeren nemli bir ortamda 24 saat inkübe edildi. Hücreler $0.5 \mu \mathrm{M}$ ile $200 \mu \mathrm{M}(0.5,1,2,5,10,20,50,100$ ve 200$)$ aralığında değişen ilaç adaylarının (S1-S6) dokuz faklı konsantrasyonuna 72 saat için maruz bırakıldı. Benzimidazolyum tuzlarının stok çözeltileri PBS de hazırlandı. Pozitif kontrol olarak metal bazlı antikanser ajan olan cisplatin kullanıld1. 72 saatlik süre tamamlandıktan sonra kuyucuklardaki DMEM vakum ile uzaklaştırıldı ve hazırlanan MTT stok çözeltisi $(50 \mu \mathrm{L}, 5$ $\mathrm{mg} / \mathrm{mL}$ ) her bir kuyucuğa ilave edildi. Plakalar 4 saat süre ile bir inkübator içerisinde tekrar inkübe edildi. Daha sonra, kuyucuklardaki ortam bir pipetör aracılığı ile dikkatli bir şekilde uzaklaştırıldı ve oluşan formazonu çözmek için $200 \mu \mathrm{L}$ DMSO her bir kuyucuğa ilave edildi. 96 kuyucuklu plaka 30 dakika boyunca bir plaka karıştırıcı üzerinde karıştırıldıktan sonra standart ELISA mikro plaka okuyucu (Biorad 6800) ile $595 \mathrm{~nm}$ de plakaların absorbans ölçümleri yapıldı. $\mathrm{IC}_{50}$ değerleri GraphPad Prism programı ile hesaplandi. Tüm bileşiklerin sitotoksik aktiviteleri üç farklı data point ve üç bağımsız çalışma ile tekrarlandi. Elde edilen sonuçların ortalaması alınarak standart sapma değerleri hesapland 1 (Tablo 2 ve 3).

\subsection{Konfokal Mikroskop Metodu}

Kanserli (HeLa) ve sağlıklı insan hücreleri (Beas2B) 12 kuyucuklu cam plakaların her bir kuyucuğuna $1 \mathrm{~mL}$ ve $5 \times 10^{4}$ yoğunlukta ekildi. Hücreler $37^{\circ} \mathrm{C}$ ve $\% 5 \mathrm{CO}_{2}$ içeren bir inkübatörde 24 saat için inkübe edildi. 24 saat sonra, negatif kontrol dişında her bir kuyucuğa final konsantrasyon $20 \mu \mathrm{M}$ olacak şekilde ilaç adayları ve cisplatin konuldu. Cam plaka bir inkübatörde 24 saat için tekrar inkübe edildi. Belirlenen süre tamamlandıktan sonra hücre ortamındaki besiyeri vakum ile uzaklaştırıldı ve her bir kuyucuk iki kez PBS ile dikkatli bir şekilde yıkandı. Her bir kuyucuğa $1 \mathrm{~mL}$ taze besiyeri konuldu ve içerisine hücreleri boyamak için $1 \mu \mathrm{g} / \mathrm{mL}$ Hoechst ve $1 \mu \mathrm{g} / \mathrm{mL}$ propidyum iyodür ilave edilerek yavaşça karıştırıldı. Cam plaka 30 dakika için tekrar inkübe edildi. Son olarak, hücrelerin renkli görüntüleri konfokal mikroskobu ile fotoğraflandı.

\section{Bulgular ve Tartışma}

\subsection{Sentezlenen Benzimidazolyum Tuzlarının Karakterizasyonu}

Literatüre göre hazırlanan bileşiklerin (S1-S6) açı yapıları Şekil 1'de verildi (Akkoç, 2019a; Akkoç vd., 2019).

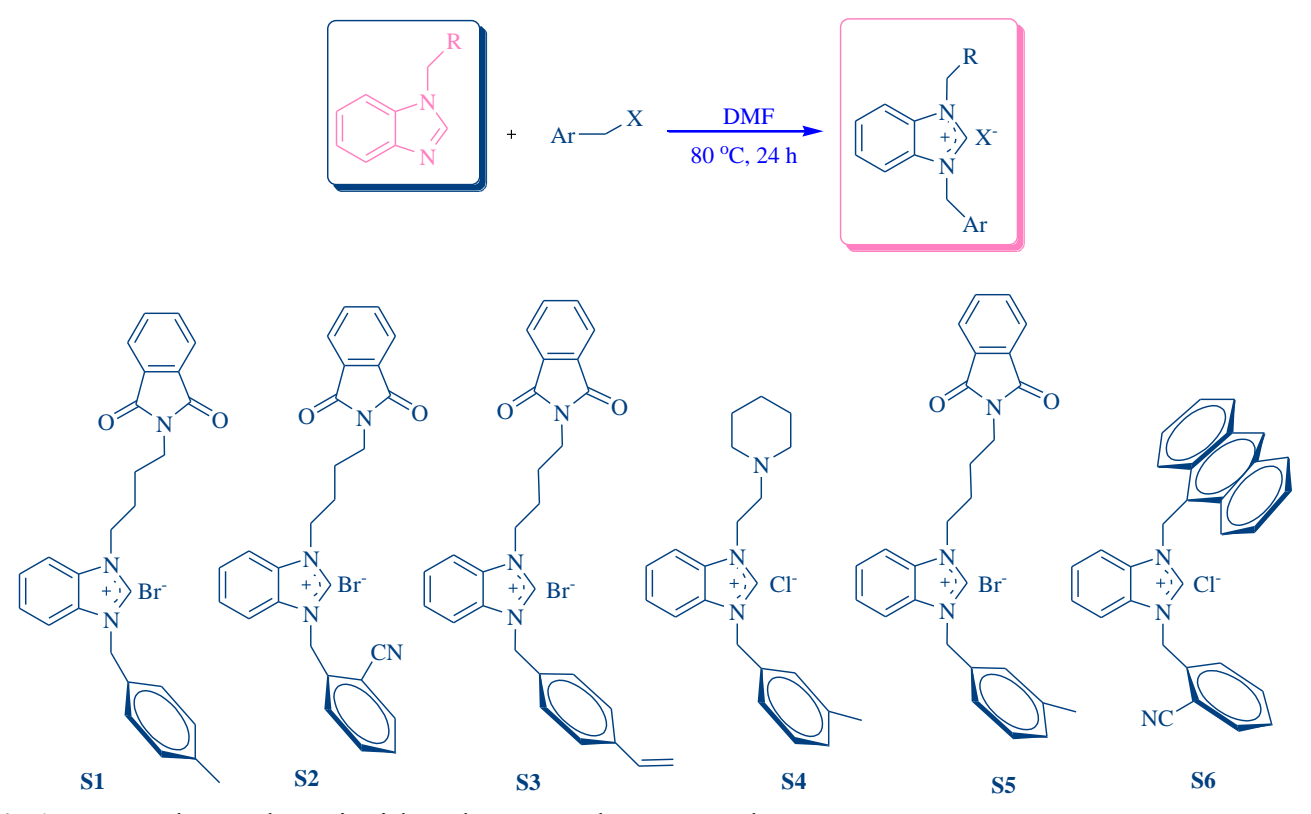

Şekil 1. Sentezlenen benzimidazolyum tuzlarının açık yapısı.

${ }^{1} \mathrm{H}$ NMR spektrumunda, aşağı alanda sırasıyla $11.56,11.56,11.55,11.40,11.54$ ve 9.17 ppm'de singlet olarak elde edilen $\mathrm{NCHN}$ pikleri, Nalkil/aril benzimidazollerden benzimidazolyum tuzlarının (S1-S6) başarılı bir şekilde sentezlendiğini desteklemektedir. ${ }^{13} \mathrm{C} \quad \mathrm{NMR}$ spektrumunda S1-S6 için NCHN karbon pikleri sirasiyla 142.77, 143.44, 142.99, 143.97, 143.01 ve 142.93 ppm'de elde edildi (Akkoç, 2019a; Akkoç vd., 2019). Benzimidazol halkasında bulunan $\mathrm{N}=\mathrm{C}$ gerilme bantlarının varlığı da (1544.9, 1562.9, 1557.6, 1558.4, 1557.7, 1553.9 
$\mathrm{cm}^{-1}$ ) tasarlanan bileşiklerin yapılarını doğrulamaktadır.

\subsection{Sentezlenen Bileşiklerin Sitotoksik Aktivite Çalışmaları}

Önceki çalışmalarımızda S1-S6 bileşiklerinin in vitro sitotoksik aktiviteleri insan meme kanser hücre hatt1 (MDA-MB-231), insan kolon kanser hücre hatt1 (DLD-1) ve insan embriyonik böbrek hücre hattına (HEK-293T) karşı test edildi (Akkoç, 2019a; Akkoç vd., 2019). Elde edilen sonuçlar Tablo 1'de verildi.
Yapılan taramalarda S2 bileşiğinin hem kanserli hem de sağlıklı hücreler üzerine bir toksik etkisinin olmadığ yani inaktif olduğu görüldü. Öte yandan, S6 bileşiğinin kanserli meme hücre hattına karşı yüksek sitotoksik etkiye sahip olduğu ve kanserli kolon hücrelerine karş1 da diğer ilaç adaylarına kıyasla daha yüksek antiproliferatif etki gösterdiği bulundu (Akkoç vd., 2019). Bu nedenle, bu çalışmada hem ilgili bileşiklerin serviks hücre hattına karşı sitotoksik etkileri hem de yüksek etkiye sahip olan S6 bileşiğinin Beas2B hücre hattına karşı seçiciliğinin olup olmadığı araştırıld1.

Tablo 1. Benzimidazolyum tuzlarının insan hücre hatlarına karşı sitotoksik aktivite sonuçları.

\begin{tabular}{|l|l|l|l|}
\hline Bileşik & MDA-MB-231 & DLD-1 & HEK-293T \\
\hline S1 & $37.43 \pm 4.38$ & $100.31 \pm 2.74$ & T.E.* \\
\hline S2 & $>200$ & $>200$ & $>100$ \\
\hline S3 & $105.95 \pm 4.84$ & $59.37 \pm 3.61$ & T.E.* \\
\hline S4 & $>100$ & T.E.* & 28.63 \\
\hline S5 & $53.35 \pm 2.05$ & $74.45 \pm 3.59$ & $48.48 \pm 4.25$ \\
\hline S6 & $1.26 \pm 0.85$ & $10.98 \pm 2.33$ & $16.22 \pm 4.20$ \\
\hline
\end{tabular}

T.E.* : Test edilmedi

Sentezlenen bileşiklerin antiproliferatif aktiviteleri HeLa ve Beas-2B hücre hatlarına karşı 72 saat için test edildi. Bu bileşiklerin $0.5 \mu \mathrm{M}$ ile $200 \mu \mathrm{M}$ arasında değişen dokuz farklı konsantrasyonu sitotoksik aktiviteyi belirlemede kullanıld1. $\mathrm{IC}_{50}$ değerleri üç bağımsız deney sonucunun ortalaması alınarak hesaplandı ve sonuçlar aşağıdaki tablolarda verildi (Tablo 2 ve 3 ).

Tablo 2. Sentezlenen bileşiklerin HeLa hücre hattına karşı in vitro sitotoksik aktivite sonuçları.

\begin{tabular}{|l|l|}
\hline \multirow{2}{*}{ Bileşik } & IC $_{\mathbf{5 0}}(\boldsymbol{\mu M})$ \\
\cline { 2 - 2 } & HeLa \\
\hline S1 & $14.57 \pm 2.01$ \\
\hline S2 & $137.50 \pm 5.33$ \\
\hline S3 & $42.34 \pm 4.83$ \\
\hline S4 & $3.72 \pm 0.14$ \\
\hline Cisplatin & $2.12 \pm 0.02$ \\
\hline
\end{tabular}

Test edilen bileşiklerin dördü de (S1-S4) HeLa hücre hattına karşı sitotoksik aktivite gösterdi. Netilpiperidin ve 3-metilbenzil grubu içeren benzimidazolyum tuzu $\mathbf{S 4}$ serviks kanserli hücre hattına karş1 $3.72 \pm 0.14 \mu \mathrm{M} \mathrm{IC}{ }_{50}$ değeri ile diğer bileşiklere kıyasla en yüksek sitotoksik aktiviteyi sergiledi. Sentezlenen bu ilaç adayının $\mathrm{IC}_{50}$ değeri, referans olarak kullanılan cisplatinin aynı hücre hattına karşı göstermiş olduğu değer ile ( $\mathrm{IC}_{50}$ : $2.12 \pm 0.02 \mu \mathrm{M})$ birbirine çok yakın olduğu bulundu.

$\mathrm{N}$-metilbenzonitril ve N-bütilfitalimit gruplarını içeren S2 kodlu bileşik $137.50 \pm 5.33 \mu \mathrm{M} \mathrm{IC}_{50}$ değeri ile $\mathrm{HeLa}$ hücreleri üzerinde diğer bileşiklere kıyasla daha az antiproliferatif aktiviteye sahiptir. 4-Metilbenzil grubu içeren S1 bileşiği $(14.57 \pm 2.01 \mu \mathrm{M})$ HeLa hücre hattına karş1 4-vinilbenzil grubu içeren S3 (42.34 \pm 4.83 $\mu \mathrm{M})$ kodlu bileşikten daha etkin olmuştur. HeLa hücrelerinin S1-S4 bileşikleri ile etkileştirildikten $72 \mathrm{~h}$ sonraki canlılık oranları Şekil 2'de verildi. 


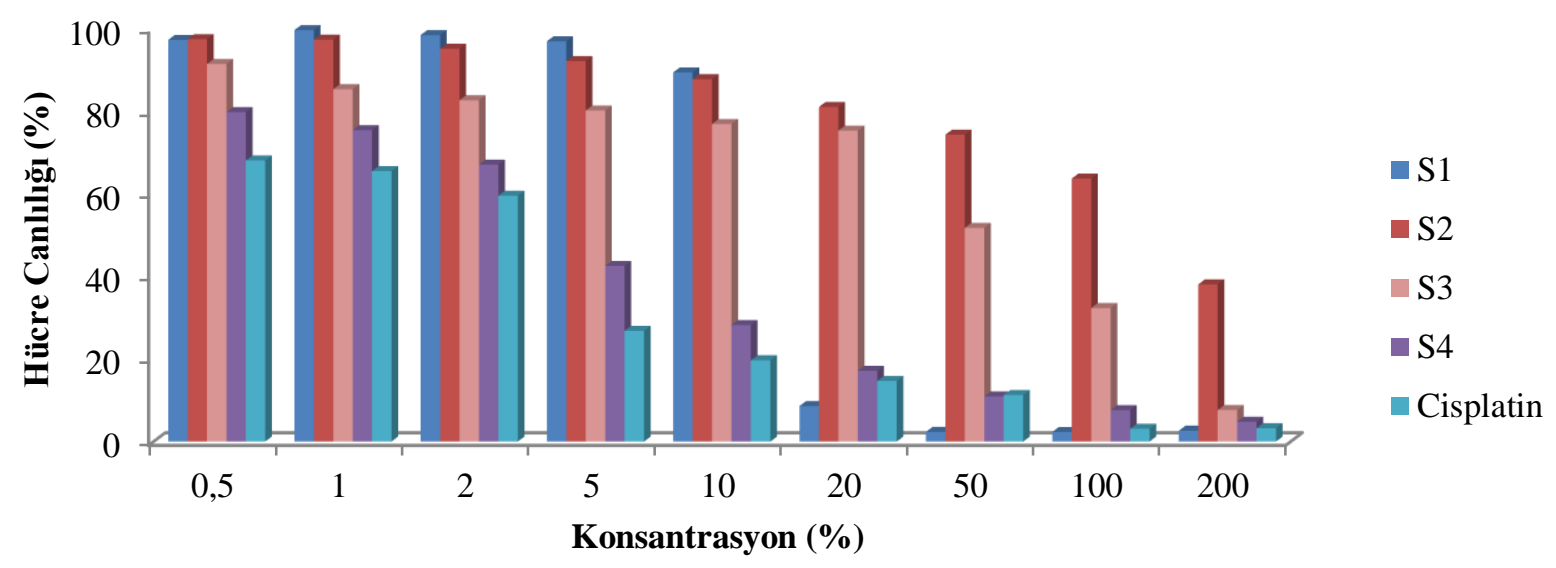

Şekil 2. Konsantrasyona bağlı olarak değişen HeLa hücrelerinin canlılık oranları.

Şekil 2'de görüldüğü gibi, sentezlenen S2 kodlu bileşik $0.5 \mu \mathrm{M}$ ve $100 \mu \mathrm{M}$ arasındaki konsantrasyonlarda serviks hücrelerine karşı gözle görülebilir bir sitotoksik aktivite göstermedi. Öte yandan, S1, S3, S4 bileşikleri ile cisplatinin sitotoksik etkisi doza bağlı olarak değişti ve yüksek konsantrasyonlarda düşük hücre canlılık oranları gözlendi. Ayrıca, S4'ün kanser hücrelerinin canlılık oranları üzerindeki etkisinin klinik ilaç olarak kullanılan cisplatin ile neredeyse eşdeğer olduğu Şekil 2 de görülmektedir. En düşük hücre canlılık oranı bileşiklerin (S1-S4 ve cisplatin) $200 \mu \mathrm{M}$ konsantrasyonunda görüldü.

S4-S6 bileşiklerinin Beas-2B hücre hatt1 üzerindeki sitotoksik etki sonuçları Tablo 3'de verildi. N-etilpiperidin ve 3-metilbenzil grubu içeren S4 bileşiği, serviks kanserli hücre hattına karş1 $3.72 \pm 0.14 \mu \mathrm{M} \quad \mathrm{IC}_{50}$ değerini gösterirken sağlıklı Beas-2B hücreleri üzerine 24 saat için $59.40 \mu \mathrm{M}$ olarak etki ettiği bulunmuştur.

3-Metilbenzil ve N-bütilfitalimit gruplarını içeren S5 ile N-metilantrasen ve N-metilbenzonitril gruplarını içeren $\mathbf{S 6}$ bileşiklerinin Beas-2B hücre hattı üzerindeki etkileri araştırıldı. Test edilen bu bileşiklerin (S5 ve S6) sağlıklı hücre hatlarında bir seçiciliğinin olmadığı ve sirası ile $120.26 \pm 5.72$ $\mu \mathrm{M}, \quad 10.76 \pm 1.44 \quad \mu \mathrm{M} \quad \mathrm{IC}_{50} \quad$ değerlerini gösterdikleri bulundu.

Tablo 3. Beas-2B hücre hattına karşı test edilen bileşiklerin in vitro sitotoksik aktivite sonuçları.

\begin{tabular}{|l|l|}
\hline \multirow{2}{*}{ Bileşik } & $\mathbf{I C}_{\mathbf{5 0}}(\boldsymbol{\mu M})$ \\
\cline { 2 - 2 } & Beas-2B \\
\hline S4 & 59.40 \\
\hline S5 & $120.26 \pm 5.72$ \\
\hline S6 & $10.76 \pm 1.44$ \\
\hline
\end{tabular}

Beas-2B hücre canlılık oranlarının, test edilen ilaç adaylarının konsantrasyonlarının azalması ile arttığı Şekil 3'de görülmektedir. S5 bileşiği 100 $\mu \mathrm{M}$ 'a kadar toksik etki çok göstermezken, konsantrasyon $200 \mu \mathrm{M}$ 'a çıkarıldığında sağlıklı hücre sayısının yaklaşık \%12 oranına kadar düştüğü görülmektedir.

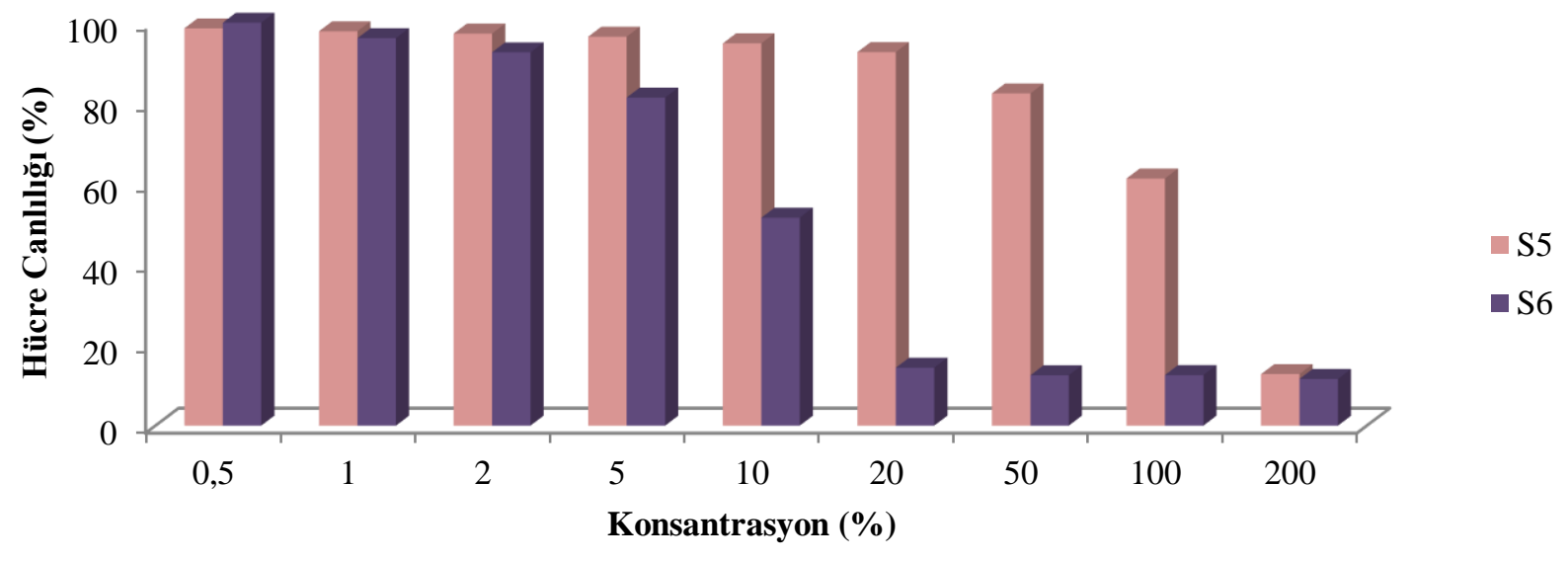

Şekil 3. Beas-2B hücrelerinin canlılık oranları. 
S6 bileşiği $1 \mu \mathrm{M}$ da $\% 4$ oranında hücreleri öldürürken, konsantrasyon $10 \mu \mathrm{M}$ 'a çıktığında hücrelerin bu ilaç adayından etkilenme oranları da \%49'a çıkmaktadır. Konsantrasyon $20 \quad \mu \mathrm{M}$ 'a çıkarıldığında ise hücrelerin bundan etkilenmelerinin çok keskin bir şekilde arttığı ve hücre ölüm oranının \%86'ya yükseldiği görülmektedir. Fakat, $20 \mu \mathrm{M}$ 'dan daha yüksek konsantrasyonlara $(50,100,200 \mu \mathrm{M}$ gibi) çıkıldığında, hücrelerin bu konsantrasyon değişiminden etkilenmediği ve canlılık oranlarının $20,50,100$ ve $200 \mu \mathrm{M}$ için surasıyla \%14.37, $\% 12.50, \% 12.53, \% 11.57$ olduğu bulundu.

\subsection{Konfokal Mikroskop Görüntüleri}

HeLa ve Beas-2B hücrelerinin görüntüleri Olimpus FV1000 Konfokal mikroskobu kullanılarak alındı. Kırmızı renkte gösterilen ölü hücrelerin ve mavi renkte gösterilen canl1 hücrelerin tanımlanmasında Hoechst (mavi) ve PI (kırmızı) floresan boyalan kullanıldı. HeLa hücreleri cisplatin ve $\mathbf{S 2}$ bileşiğine 24 saat için maruz bırakıldı (Şekil 4).

Negatif kontrol grupta hücreler canlıliklarını devam ettirirken, pozitif kontrol grupta (cisplatin uygulanan) hücrelerin büyük oranının öldüğ̈̈ Şekil 4'de verilen fotoğraflarda görülmektedir. Konfokal görüntüleri, cisplatin ve $\mathbf{S 2}$ bileşiğinin HeLa üzerindeki MTT sonuçlarını doğrulamaktadir.

Negatif kontrolün konfokal görüntülerinde hücrelerin canlılıklarını tamamen korudukları Şekil 5'de verilen ilk resimde görülmektedir. Fakat, S5 ve S6 bileşikleri ile muamele edilen hücrelerin canlılık oranlarının negatif kontrole kıyasla çok düştüğü ve S6 bileşiğinin S5 bileşiğinden daha toksik etkiye sahip olduğu alınan fotoğraflarda görülmektedir. Sonuç olarak, MTT sonuçları ile konfokal görüntülerinden elde edilen sonuçlar birbirini desteklemektedir.
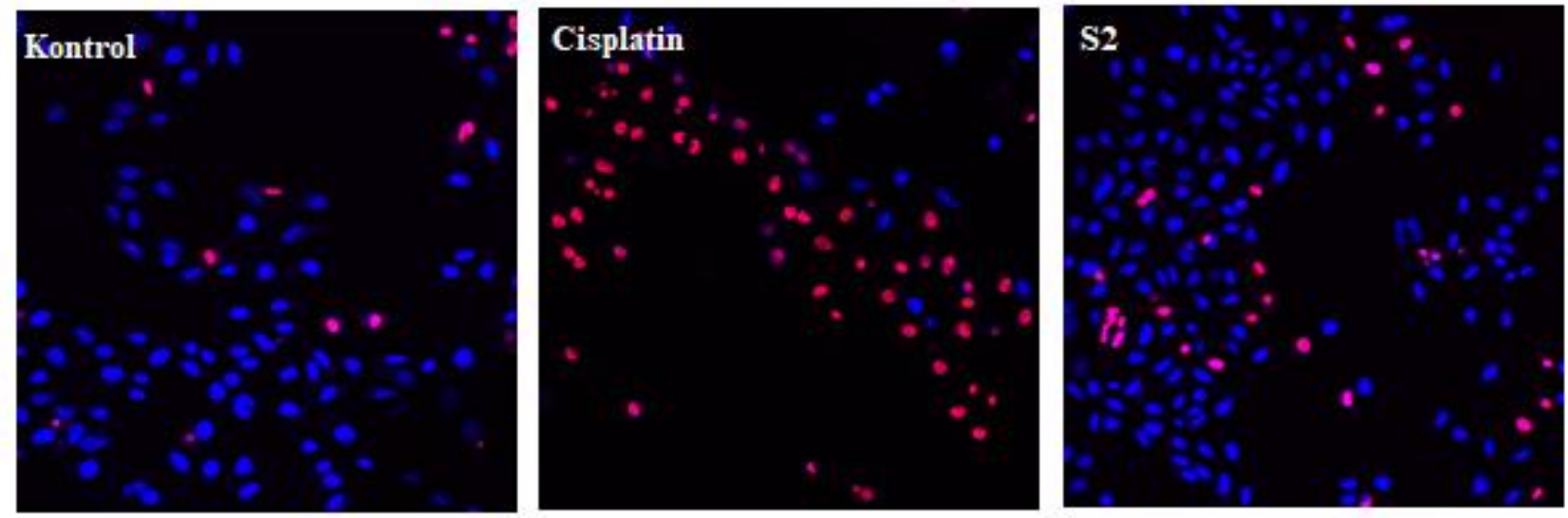

Şekil 4. HeLa hücrelerinin cisplatin ve $\mathbf{S 2}$ uygulandıktan 24 saat sonraki konfokal görüntüleri.
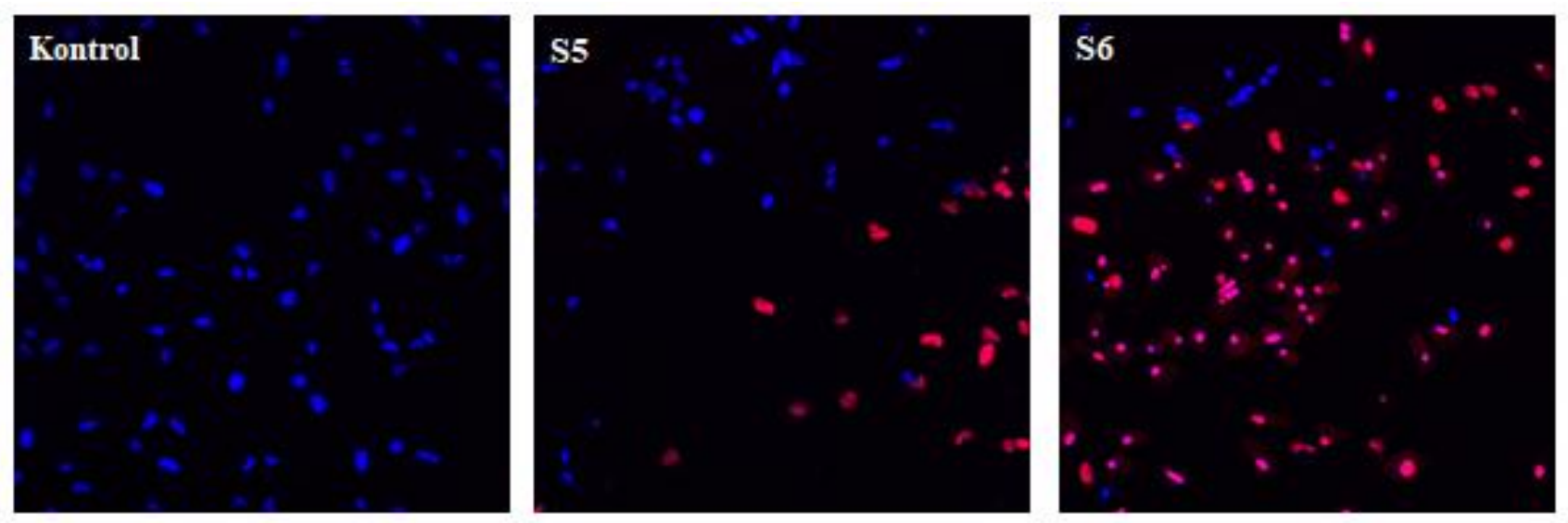

Şekil 5. Beas-2B hücrelerinin ilaç adayları uygulandıktan 24 saat sonraki konfokal görüntüleri. 


\section{Sonuçlar}

Çalı̧ma kapsamında öncelikle farklı Nalkilbenzimidazol türevleri hazırlandı. $\mathrm{Bu}$ türevlerden yararlanarak altı benzimidazolyum tuzu sentezlendi. Sentezlenen bileşiklerin sitotoksik aktiviteleri HeLa ve Beas-2B hücre hatlarına karşı test edildi. $\mathrm{Bu}$ bileşiklerden özellikle S4 bileşiğinin $3.72 \pm 0.14 \mu \mathrm{M} \quad \mathrm{IC}_{50}$ değeri ile antikanser ilaç adayı olma yönünde önemli bir potansiyele sahip olduğu belirlendi.

\section{Kaynaklar}

Abdelgawad, M.A., Bakr, R.B., Ahmad, W., Al-Sanea, M.M. ve Elshemy, H.A.H., 2019. New Pyrimidine-Benzoxazole/Benzimidazole Hybrids: Synthesis, Antioxidant, Cytotoxic Activity, In Vitro Cyclooxygenase and Phospholipase A2-V Inhibition. Bioorganic Chemistry, 92, 103218.

Akkoç, S., 2019a. Derivatives of 1-(2-(Piperidin-1yl)ethyl)-1H-benzo[d]imidazole: Synthesis, Characterization, Determining of Electronic Properties and Cytotoxicity Studies. ChemistrySelect, 4, 4938-4943.

Akkoç, S., 2019b. Antiproliferative Activities of 2Hydroxyethyl Substituted Benzimidazolium Salts and Their Palladium Complexes Against Human Cancerous Cell Lines. Synthetic Communications, 49, 2903-2914.

Akkoç, S., Kayser, V. ve İlhan, İ.Ö., 2019. Synthesis and In Vitro Anticancer Evaluation of Some Benzimidazolium Salts. Journal of Heterocyclic Chemistry, 56, 2934-2944.

Akkoç, S., Kayser, V., İlhan, İ.Ö., Hibbs, D.E., Gök, Y., Williams, P.A., Hawkins, B. ve Lai, F., 2017. New Compounds Based on a Benzimidazole Nucleus: Synthesis, Characterization and Cytotoxic Activity Against Breast and Colon Cancer Cell Lines. Journal of Organometallic Chemistry, 839, 98-107.

Akkoç, S., Özer İlhan, İ., Gök, Y., Upadhyay, P.J. ve Kayser, V., 2016. In Vitro Cytotoxic Activities of New Silver and PEPPSI Palladium Nheterocyclic Carbene Complexes Derived from Benzimidazolium Salts. Inorganica Chimica Acta, 449, 75-81.

Aslan, H.G., Akkoç, S. ve Kökbudak, Z., 2020. Anticancer Activities of Various New Metal Complexes Prepared from a Schiff Base on A549 Cell Line. Inorganic Chemistry Communications, 111, 107645.

Bansal, Y. ve Silakari, O., 2012. The Therapeutic Journey of Benzimidazoles: A Review.
Bioorganic Medicinal Chemistry, 20, 62086236.

Busschots, S., O’Toole, S., O’Leary, J.J. ve Stordal, B., 2015. Carboplatin and Taxol Resistance Develops More Rapidly in Functional BRCA1 Compared to Dysfunctional BRCA1 Ovarian Cancer Cells. Experimental Cell Research, 336, $1-14$.

Cheng, J., Xie, J. ve Luo, X., 2005. Synthesis and Antiviral Activity Against Coxsackie Virus B3 of Some Novel Benzimidazole Derivatives. Bioorganic and Medicinal Chemistry Letters, $15,267-269$.

Farahat, A.A., Ismail, M.A., Kumar, A., Wenzler, T., Brun, R., Paul, A., Wilson, W.D. ve Boykin, D.W., 2018. Indole and Benzimidazole Bichalcophenes: Synthesis, DNA Binding and Antiparasitic Activity. European Journal of Medicinal Chemistry, 143, 1590-1596.

Gök, Y., Akkoç, S., Çelikal, Ö.Ö., Özdemir, İ. ve Günal, S., 2019. In Vitro Antimicrobial Studies of Naphthalen-1-ylmethyl Substituted Silver Nheterocyclic Carbene Complexes. Arabian Journal of Chemistry, 12, 2513-2518.

Gök, Y., Akkoç, S., Çelikal, Ö.Ö., Özdemir, İ., Günal, S. ve Sayin, E., 2013. N-Functionalized Benzimidazol-2-ylidene Silver Complexes: Synthesis, Characterization and Antimicrobial Studies. Turkish Journal of Chemistry, 37 (6) 1007-1013.

Özil, M., Parlak, C. ve Baltaş, N., 2018. A Simple and Efficient Synthesis of Benzimidazoles Containing Piperazine or Morpholine Skeleton at C-6 Position as Glucosidase Inhibitors with Antioxidant Activity. Bioorganic Chemistry, 76, 468-477.

Rojas-Aguirre, Y., Castillo, I., Hernández, D.J., Nogueda-Torres, B., Márquez-Navarro, A., Villalobos, J.C., Sánchez-Bartéz, F., SánchezTorres, L., Gracia-Mora, I., Castillo, R. ve Hernández-Luis, F., 2012. Diversity in the Supramolecular Interactions of 5,6-Dichloro-2(trifluoromethyl)-1H-benzimidazole with Modified Cyclodextrins: Implications for Physicochemical Properties and Antiparasitic Activity. Carbohydrate Polymers, 87, 471-479.

Rosenberg, B., Vancamp, L., Trosko, J.E. ve Mansour, V.H. 1969. Platinum Compounds: a New Class of Potent Antitumour Agents. Nature, 222, 385386.

Sharma, R., Bali, A. ve Chaudhari, B.B., 2017. Synthesis of MethanesulphonamidoBenzimidazole Derivatives as Gastro-sparing Antiinflammatory Agents with Antioxidant 
Effect. Bioorganic and Medicinal Chemistry Letters, 27, 3007-3013.

Shingalapur, R.V., Hosamani, K.M., Keri, R.S. ve Hugar, M.H., 2010. Derivatives of Benzimidazole Pharmacophore: Synthesis, Anticonvulsant, Antidiabetic and DNA Cleavage Studies. European Journal of Medicinal Chemistry, 45, 1753-1759.

Taha, M., Mosaddik, A., Rahim, F., Ali, S., Ibrahim, M. ve Almandil, N.B., 2018. Synthesis, Antiglycation and Antioxidant Potentials of Benzimidazole Derivatives. Journal of King Saud University - Science, 32, 191-194.

To, K.K.W., Poon, D.C., Wei, Y., Wang, F., Lin, G. ve Fu, L.W., 2016. Data Showing the Circumvention of Oxaliplatin Resistance by Vatalanib in Colon Cancer. Data in Brief, 7, 437-444.

Tonelli, M., Novelli, F., Tasso, B., Vazzana, I., Sparatore, A., Boido, V., Sparatore, F., La
Colla, P., Sanna, G., Giliberti, G., Busonera, B., Farci, P., Ibba, C. ve Loddo, R., 2014. Antiviral Activity of Benzimidazole Derivatives. III. Novel Anti-CVB-5, Anti-RSV and Anti-Sb-1 Agents. Bioorganic Medicinal Chemistry, 22, 4893-4909.

Wheate, N.J., Walker, S., Craig, G.E. ve Oun, R., 2010. The Status of Platinum Anticancer Drugs in the Clinic and in Clinical Trials. Dalton Transactions, 39, 8113-8127.

World Health Organization, 2018. Cancer, http://www.who.int/news-room/fact sheets/detail/cancer. 07 Kasim 2019.

Yang, Y., Guo, L., Ge, X., Shi, S., Gong, Y., Xu, Z., Zheng, X. ve Liu, Z., 2019. Structure-Activity Relationships for Highy Potent Half-Sandwich Organoiridium (III) Anticancer Complexes with $\mathrm{C}^{\wedge} \mathrm{N}-\mathrm{Ch}$ lated Ligands. Journal of Inorganic Biochemistry, 191, 1-7. 